\title{
Toxicity of insecticides to predators of rice brown planthopper: Wolf spider and carabid beetle
}

\author{
Md. Jahangir Alam*, Gopal Das \\ Entomology Division, Bangladesh Tea Research Institute, Srimangal, Moulvibazar, Bangladesh
}

(Received: 24-10-2019; Revised: 22-07-2020; Accepted: 23-07-2020; Published: 09-08-2020)

${ }^{*}$ Corresponding author (E-mail: anikbau52@gmail.com)

\begin{abstract}
Field toxicity of two insect growth regulators (IGR) viz. Award 40 SC (Buprofezin) and Haron 5 EC (Lufenuron) and one newer Thiacloprid viz. Calypso 280 SC against wolf spider, Lycosa pseudoannulata and carabid beetle, Ophionea indica, the predators of rice brown planthopper (BPH) was examined in the Entomology field laboratory, Bangladesh Agricultural University, Mymensingh. Effectiveness of insecticides was assessed on the basis of populations of wolf spider and carabid beetle under field condition at 1 , 2, 3, 5 \& 7 days after treatment. The abundances of wolf spider and carabid beetle were not changed significantly even when rice plants were treated with either Award or Haron. In contrast, Calypso 280 SC had significantly reduced wolf spiders (about $78 \%$ ) and carabid beetle (about 57\%) populations compared to the control. Therefore it is concluded from the present study that Award 40 SC@ $0.75 \mathrm{ml} / \mathrm{L}$ or Haron 5 EC @ $1.00 \mathrm{ml} / \mathrm{L}$ would be applied as the protector of predators of BPH in rice-ecosystem. On the other hand, Calypso 280 SC has adverse effects on the populations of wolf spider and carabid beetle in rice-ecosystem as well as other environmental components.
\end{abstract}

Key words: Insecticides, Predators, Rice brown plant hopper, Lycosa pseudoannulata, Ophionea indica

\section{INTRODUCTION}

Pesticides are major agents used to control agricultural pests. In Bangladesh, insecticides have been widely used for controlling insect's pests in most rice paddies and others. Intensive and extensive use of insecticides, however, has causal several problems: development of insecticides resistance in pest insects, environmental pollution and side effects on non-target organisms including the natural enemies of the target pests (Kiritani, 1979). Biswas et al., (2006) evaluated the toxic action of two insecticides (Cypermethrin and Carbofuran) against M. discolor and L. pseudoannulata, where L. pseudoannulata was more susceptible to the insecticides than $M$. discolor. Use of selective insecticides that are less toxic to natural enemies and the natural enemies may suppress the pest populations, which in turn will reduce the rate of insecticide application.

Predation is the ecological process by which energy is transferred from living animal to living animal based on the behavior of a predator that captures and kills a prey before eating it. To effectively utilize the natural enemies as biological control agents, it is necessary to acquire the information about the effects of pesticides on them. Tanaka et al., reported many insecticides, particularly phenthoate, imidacloprid and deltamethrin, were toxic to C. lividipennis and also evaluated the destructive effects of deltamethrin on the spider populations with induced a resurgence of the $N$. lugens population.

The wolf spider, Lycosa pseudoannulata (Boesenberg et strand) is one of the most important predators of BPH and can consume 15-20 adult plant hoppers per day (Samal and Misra, 1975). The feeding efficiency of Lycosa pseudoannulata has been estimated to be 24 nymphs or adults of $N$. lugens per day. L. pseudoannulata may serve as an effective biocontrol agent of BPH in Bangladesh. Ophionea indica (Coleoptera: Carabidae) is one of the important predator of nymph and adult of brown planthopper (Ali Khan and Yusuf, 1986). Both the grubs and adults of the carabid beetle are reported as an important predator of brown planthopper (Samal and Misra, 1984). It is found to maintain a good predator prey relationship between carabid beetle and brown planthopper (Bonn and Kleinwachter, 1999).

The most commonly practiced method of controlling brown planthopper in Bangladesh is the application of synthetic insecticides. Uses of synthetic insecticides providing temporary control and furthermore it is evident that the use of broad-spectrum pesticide has almost inevitably been followed by the development of pesticide resistance, pest resurgence and out breaks of secondary pest etc and especially on natural enemies (Luckmann and Metcalf, 1975; Husain, 1993). Hence, the present study was taken to evaluate the toxicity of insecticides on the abundances of two predators Lycosa pseudoannulata and Ophionea indica of BPH with different concentrations under field condition.

\section{MATERIALS AND METHODS}

The experiment was conducted in the field laboratory of the Department of Entomology, Bangladesh Agricultural 
University (BAU), Mymensingh during the period from February to June, 2015. The experiment was conducted in a Randomized Complete Block Design (RCBD). The experiment consisting of 10 treatments while each of the treatment was replicated thrice. The whole experimental field was divided into 3 equal blocks and each block was then divided into 10 plots. Finally a total of 30 plots were made in the specified area for conducting the experiments. The size of a unit plot was $4.0 \mathrm{~m} \mathrm{X} 2.5 \mathrm{~m}$. Two adjacent unit plots and blocks were separated by $50 \mathrm{~cm}$ and $80 \mathrm{~cm}$ apart respectively. Plots were allocated randomly and they were separated in such way so that impact of treatments can be quantified.

The experiment was conducted with the rice variety, TN-1 (Taichung Native-1) as this variety is highly susceptible to BPH infestation. Ploughed soil was brought into desirable final tilth by four operations of ploughing and laddering with country plough and also by cross ploughing followed by laddering. Seedlings of $\mathrm{TN}-1$ were collected from the farm of Bangladesh Institute of Nuclear Agriculture (BINA), Mymensingh. Collected seedlings were transplanted immediately in the main field on $2^{\text {nd }}$ February, 2015. The plant spacing was followed as $20 \mathrm{~cm} \times 15 \mathrm{~cm}$. Eight (8) to ten (10) $\mathrm{cm}$ water was maintained by irrigation throughout the period of experiment because the test insect, Nilaparvata lugens is a water-loving insect. The boarder or boundary of each subplot was so high that irrigated water could not move from one plot to another plot.

\section{Selection of treatments}

Two IGR based biopesticides namely, Buprofezin and lufenuron and one synthetic insecticide of neo-nicotinoid were selected to determine the effects of mortality. There were ten treatments including control with three replications for each. The detailed specifications of treatments are presented in the table 1 with their doses, trade name and group.

All the treatments were applied according to the experimental specifications. Two consecutive sprays were given at 45 and 60 DAT (days after transplantation) with pneumatic knapsack sprayer. Spraying was done in the morning time to avoid bright sun shine. Data were collected on before treatment application and 1,2,3,5 and 7 days after treatment (DAT) application. Data were also collected from untreated control plot.

Data were collected using the following parameters

The mean number of wolf spider and carabid beetle populations per hill was calculated using the following formula:

$\%$ Decrease over control $=\frac{\mathrm{Pc}-\mathrm{Pt}}{\mathrm{Pc}} \times 100$

Where,

$\mathrm{Pt}=$ Number of predators after treatment application

$\mathrm{Pc}=$ Number of predators without treatment application

(Control)
Table 1: Specification of treatments of the selected insecticides

\begin{tabular}{|c|c|c|c|}
\hline & Treatments & $\begin{array}{l}\text { Active } \\
\text { ingredients }\end{array}$ & Group \\
\hline $\mathrm{T}_{1}$ & $\begin{array}{l}\text { Award } 40 \text { SC @ } \\
0.25 \mathrm{ml} / \mathrm{L} \text { water }\end{array}$ & Buprofezin & $\begin{array}{l}\text { Insect Growth } \\
\text { Regulator }\end{array}$ \\
\hline $\mathrm{T}_{2}$ & $\begin{array}{l}\text { Award 40 SC @ } \\
0.50 \mathrm{ml} / \mathrm{L} \text { water }\end{array}$ & Buprofezin & $\begin{array}{l}\text { Insect Growth } \\
\text { Regulator }\end{array}$ \\
\hline $\mathrm{T}_{3}$ & $\begin{array}{l}\text { Award 40 SC @ } \\
0.75 \text { ml/Lwater }\end{array}$ & Buprofezin & $\begin{array}{l}\text { Insect Growth } \\
\text { Regulator }\end{array}$ \\
\hline $\mathrm{T}_{4}$ & $\begin{array}{l}\text { Haron5 EC @ } \\
0.50 \mathrm{ml} / \mathrm{L} \text { water }\end{array}$ & Lufenuron & $\begin{array}{l}\text { Insect Growth } \\
\text { Regulator }\end{array}$ \\
\hline $\mathrm{T}_{5}$ & $\begin{array}{l}\text { Haron5 EC @ } \\
1.00 \mathrm{ml} / \mathrm{L} \text { water }\end{array}$ & Lufenuron & $\begin{array}{l}\text { Insect Growth } \\
\text { Regulator }\end{array}$ \\
\hline $\mathrm{T}_{6}$ & $\begin{array}{l}\text { Haron 5 EC @ } \\
1.5 \text { ml/L water }\end{array}$ & Lufenuron & $\begin{array}{l}\text { Insect Growth } \\
\text { Regulator }\end{array}$ \\
\hline $\mathrm{T}_{7}$ & $\begin{array}{l}\text { Calypso 280 SC @ } \\
0.50 \mathrm{ml} / \mathrm{L} \text { water }\end{array}$ & Thiacloprid & Neo-nicotinoid \\
\hline $\mathrm{T}_{8}$ & $\begin{array}{l}\text { Calypso 280 SC @ } \\
0.75 \mathrm{ml} / \mathrm{L} \text { water }\end{array}$ & Thiacloprid & Neo-nicotinoid \\
\hline $\mathrm{T}_{9}$ & $\begin{array}{l}\text { Calypso } 280 \text { SC @ } \\
1.00 \mathrm{ml} / \mathrm{L} \text { water }\end{array}$ & Thiacloprid & Neo-nicotinoid \\
\hline $\mathrm{T}_{10}$ & Control & ----- & ----- \\
\hline
\end{tabular}

The recorded data were compiled and tabulated for statistical analysis. Analysis of variance was done with the help of computer package MSTAT. The mean differences among the treatments were adjudged with Duncan's Multiple Range Test (DMRT) and Least Significant Difference (LSD) when necessary (Gomez and Gomez, 1984).

\section{RESULTS AND DISCUSSION}

\section{Abundances of wolf spider, L. pseudoannulata and carabid beetle, $O$. indica in rice- ecosystem following treated with different treatments}

Abundances of wolf spiders, L. pseudoannulata and carabid beetles, $O$. indica in rice-ecosystem following treated with different concentrations of Award 40 SC

It was observed that the populations of wolf spiders and carabid beetles in rice-ecosystem were not changed significantly when rice plants were treated with different concentrations of Award $40 \mathrm{SC}$ in comparison with that of control (Table 2). This result is consistent with the previous findings that Award 40 SC (Buprofezin) is harmless for on non-target organisms or natural enemies (Choi et al., 1996; GuiFen and ChuanTao, 1996). It was also reported by Mendel et al., (1994) that Buprofezin did not adversely affect egg hatch and larval development of Elatophilus hebraicus (Hemiptera: Anthocoridae). Deng et al., (2008) also reported that Buprofezin had low toxicity to wolf spider, Piratapiratoides. The present finding was also supported by Thang et al., (1987) where they have reported that Buprofezin had the least adverse effect on L. pseudoannulata. 
Abundances of wolf spiders, L. pseudoannulata and carabid beetles, $O$. indicain rice-ecosystem following treated with different concentrations of Haron 5 EC

Like as Buprofezin, Haron 5 EC (Lufenuron) had no significant effects on the abundances of L. pseudoannulata and $O$. indica in rice-ecosystem (Table 3). Before treatment applications, wolf spiders and carabid beetles were approximately 3 and 2 per hill respectively and these numbers were not changed significantly even when rice plants were treated with different concentrations of Haron. This result suggests that Haron 5 EC (a chitin synthesis inhibitor) is safe for wolf spider and carabid beetle in rice-ecosystem. Aulakh and Butter (2009) used Lufenuron (Match 5 EC) @ 24, 50, 255 and 290 ppm against cotton bollworms particularly, Helicoverpa armigera (Hübner) proved safe to eggs and adults of Chrysoper lacarnea (Stephens) at all the dosages which helped in the conservation of natural fauna. The present findings is also supported by the Gogi et al,. (2006) where they have reported that Lufenuron and Buprofezin had the minimum or no effect on the predators in rice-ecosystem.
Abundances of wolf spiders, L. pseudoannulata and carabid beetles, $O$. indicain rice-ecosystem treated with different concentrations of Calypso 280 SC

Wolf spider and carabid beetle populations were significantly reduced after application of different doses of Calypso 280 SC $(\mathrm{P}<0.01$, Table 4$)$. Both natural enemies were reduced significantly at $1 \mathrm{DAT}$ while the lowest numbers were recorded at $3 \mathrm{DAT}$ and this reduction was persisted up to day 7 . The similar trend was found in case of BPH mortality where $50 \%$ mortality was found at 1 DAT and reached at peak level by day 3 .

Similar results were also obtained by Zeng et al., (2010) where they have reported that spiders populations were decreased 42.86 to $60.90 \%$ at 7 DAT when Thiacloprid 48 SC was applied @ 45-63 g a.i./ha. Ullah and Jahan (2004) reported that carabid beetles, $O$. Indica populations were changed significantly compared to the control due to the application of Brifer $5 \mathrm{G}$ and Azodrin 40 WSC. Neo-nicotinoid insecticides had a destructive effect on the populations of spiders, mirid bug and dryinid wasp (Tanaka et al., 2000).

Table 2: Abundances of wolf spiders, L. pseudoannulata and carabid beetles, O. indica in rice-ecosystem following treated with different concentrations of Award 40 SC

\begin{tabular}{|c|c|c|c|c|c|c|c|c|c|c|c|c|}
\hline \multirow[t]{2}{*}{ Treatment } & \multicolumn{6}{|c|}{$\begin{array}{c}\text { Mean number of L. pseudoannulata per hill at } \\
\text { different DAT }\end{array}$} & \multicolumn{6}{|c|}{$\begin{array}{c}\text { Mean number of } O \text {. indica per hill at different } \\
\text { DAT }\end{array}$} \\
\hline & $\begin{array}{l}\text { Pre-treated } \\
\text { populations }\end{array}$ & $\begin{array}{c}1 \\
\text { DAT }\end{array}$ & $\begin{array}{c}2 \\
\text { DAT }\end{array}$ & $\begin{array}{c}3 \\
\text { DAT }\end{array}$ & $\begin{array}{c}5 \\
\text { DAT }\end{array}$ & $\begin{array}{c}7 \\
\text { DAT }\end{array}$ & $\begin{array}{l}\text { Pre-treated } \\
\text { populations }\end{array}$ & $\begin{array}{c}1 \\
\text { DAT }\end{array}$ & $\begin{array}{c}2 \\
\text { DAT }\end{array}$ & $\begin{array}{c}3 \\
\text { DAT }\end{array}$ & $\begin{array}{c}5 \\
\text { DAT }\end{array}$ & $\begin{array}{c}7 \\
\text { DAT }\end{array}$ \\
\hline Award 40 SC @ 0.25 ml/L & 3.46 & 3.46 & 3.46 & 3.46 & 3.33 & 3.33 & 2.33 & 2.33 & 2.33 & 2.33 & 2.22 & 2.22 \\
\hline Award 40 SC @ 0.50 ml/L & 3.36 & 3.36 & 3.36 & 3.36 & 3.16 & 3.16 & 2.00 & 2.00 & 2.00 & 2.00 & 1.95 & 1.85 \\
\hline Award40 SC@0.75 ml/L & 3.60 & 3.60 & 3.60 & 3.60 & 3.23 & 3.23 & 2.06 & 2.06 & 2.06 & 2.06 & 1.96 & 1.89 \\
\hline Control & 3.73 & 3.73 & 3.73 & 3.73 & 3.66 & 3.66 & 2.30 & 2.30 & 2.30 & 2.30 & 2.20 & 2.20 \\
\hline P-level & NS & NS & NS & NS & NS & NS & NS & NS & NS & NS & NS & NS \\
\hline CV\% & 3.43 & 3.43 & 3.43 & 3.43 & 1.99 & 1.99 & 3.16 & 3.16 & 3.16 & 3.16 & 6.16 & 6.16 \\
\hline $\mathrm{SE}( \pm)$ & 0.08 & 0.08 & 0.08 & 0.08 & 0.11 & 0.13 & 0.08 & 0.08 & 0.08 & 0.14 & 0.13 & 0.13 \\
\hline
\end{tabular}

In a column, means of similar letter (s) do not differ significantly. DAT = Days After Treatment, P-level = Probability Level, CV = Co-efficient of Variation, $\mathrm{SE}=$ Standard Error.

Table 3: Abundances of wolf spiders, L. pseudoannulata and carabid beetles, O. indica in rice-ecosystem following treated with different concentrations of Haron 5 EC

\begin{tabular}{|c|c|c|c|c|c|c|c|c|c|c|c|c|}
\hline \multirow[t]{2}{*}{ Treatment } & \multicolumn{6}{|c|}{$\begin{array}{c}\text { Mean number of L. pseudoannulata per hill at } \\
\text { different DAT }\end{array}$} & \multicolumn{6}{|c|}{$\begin{array}{c}\text { Mean number of } O \text {. indica per hill at different } \\
\text { DAT }\end{array}$} \\
\hline & $\begin{array}{l}\text { Pre-treated } \\
\text { populations }\end{array}$ & $\begin{array}{c}1 \\
\text { DAT }\end{array}$ & $\begin{array}{c}2 \\
\text { DAT }\end{array}$ & $\begin{array}{c}3 \\
\text { DAT }\end{array}$ & $\begin{array}{c}5 \\
\text { DAT }\end{array}$ & $\begin{array}{c}7 \\
\text { DAT }\end{array}$ & $\begin{array}{l}\text { Pre-treated } \\
\text { populations }\end{array}$ & $\begin{array}{c}1 \\
\text { DAT }\end{array}$ & $\begin{array}{c}2 \\
\text { DAT }\end{array}$ & $\stackrel{3}{\text { DAT }}$ & $\begin{array}{c}5 \\
\text { DAT }\end{array}$ & $\begin{array}{c}7 \\
\text { DAT }\end{array}$ \\
\hline Haron 5 EC@ @ 0.50 ml/L & 3.60 & 3.60 & 3.60 & 3.60 & 3.46 & 3.46 & 2.44 & 2.44 & 2.44 & 2.44 & 2.33 & 2.33 \\
\hline Haron5 EC@1.00 ml/L & 3.66 & 3.66 & 3.66 & 3.66 & 3.50 & 3.50 & 2.10 & 2.10 & 2.10 & 2.10 & 1.99 & 1.99 \\
\hline Haron5 EC @ 1.50 ml/L & 3.66 & 3.66 & 3.66 & 3.66 & 3.23 & 3.23 & 2.00 & 2.00 & 2.00 & 2.00 & 1.89 & 1.89 \\
\hline Control & 3.66 & 3.66 & 3.66 & 3.66 & 3.66 & 3.66 & 2.30 & 2.30 & 2.30 & 2.30 & 2.20 & 2.20 \\
\hline P-level & NS & NS & NS & NS & NS & NS & NS & NS & NS & NS & NS & NS \\
\hline CV\% & 2.69 & 2.69 & 2.69 & 2.69 & 1.59 & 1.59 & 2.25 & 2.25 & 2.25 & 2.25 & 3.74 & 3.74 \\
\hline $\operatorname{SE}( \pm)$ & 0.03 & 0.03 & 0.03 & 0.04 & 0.09 & 0.11 & 0.10 & 0.10 & 0.10 & 0.12 & 0.10 & 0.10 \\
\hline
\end{tabular}

In a column, means of similar letter (s) do not differ significantly. DAT = Days After Treatment, P-level = Probability Level, CV = Co-efficient of Variation, $\mathrm{SE}=$ Standard Error. 
Table 4: Abundances of wolf spiders, L. pseudoannulata and carabid beetles, O. indica in rice-ecosystem following treated with different concentrations of Calypso 280 SC

\begin{tabular}{|c|c|c|c|c|c|c|c|c|c|c|c|c|}
\hline \multirow[t]{2}{*}{ Treatment } & \multicolumn{6}{|c|}{$\begin{array}{c}\text { Mean number of } L . \text { pseudoannulata per hill at } \\
\text { different DAT }\end{array}$} & \multicolumn{6}{|c|}{$\begin{array}{c}\text { Mean number of } O \text {. indica per hill at different } \\
\text { DAT }\end{array}$} \\
\hline & $\begin{array}{l}\text { Pre-treated } \\
\text { populations }\end{array}$ & $\begin{array}{c}1 \\
\text { DAT }\end{array}$ & $\begin{array}{c}2 \\
\text { DAT }\end{array}$ & $\begin{array}{c}3 \\
\text { DAT }\end{array}$ & $\begin{array}{c}5 \\
\text { DAT }\end{array}$ & $\begin{array}{c}7 \\
\text { DAT }\end{array}$ & $\begin{array}{l}\text { Pre-treated } \\
\text { populations }\end{array}$ & $\begin{array}{c}1 \\
\text { DAT }\end{array}$ & $\begin{array}{c}2 \\
\text { DAT }\end{array}$ & $\begin{array}{c}3 \\
\text { DAT }\end{array}$ & $\begin{array}{c}5 \\
\text { DAT }\end{array}$ & $\begin{array}{c}7 \\
\text { DAT }\end{array}$ \\
\hline Calypso 280 SC @ 0.50 ml/L & 4.00 & $3.00^{\mathrm{b}}$ & $2.56^{\mathrm{b}}$ & $2.06^{\mathrm{b}}$ & $1.90^{\mathrm{b}}$ & $1.90^{\mathrm{b}}$ & 2.33 & $1.88^{\mathrm{b}}$ & $1.78^{\mathrm{b}}$ & $1.66^{\mathrm{b}}$ & $1.66^{\mathrm{b}}$ & $1.66^{\mathrm{b}}$ \\
\hline Calypso280 SC @ 0.75 ml/L & 3.83 & $2.66^{c}$ & $2.06^{\mathrm{c}}$ & $0.90^{c}$ & $0.83^{c}$ & $0.83^{\mathrm{c}}$ & 2.11 & $1.55^{c}$ & $1.16^{\mathrm{d}}$ & $0.99^{c}$ & $0.99^{c}$ & $0.99^{c}$ \\
\hline Calypso280 SC @1.00 ml/L & 4.06 & $2.93^{\mathrm{b}}$ & $2.00^{c}$ & $0.83^{\mathrm{c}}$ & $0.83^{c}$ & $0.83^{c}$ & 2.22 & $1.55^{\mathrm{c}}$ & $1.33^{\mathrm{c}}$ & $1.00^{c}$ & $1.00^{c}$ & $1.00^{c}$ \\
\hline Control & 3.73 & $3.73^{\mathrm{a}}$ & $3.73^{\mathrm{a}}$ & $3.73^{\mathrm{a}}$ & $3.66^{\mathrm{a}}$ & $3.66^{\mathrm{a}}$ & 2.30 & $2.30^{\mathrm{a}}$ & $2.30^{\mathrm{a}}$ & $2.30^{\mathrm{a}}$ & $2.30^{\mathrm{a}}$ & $2.30^{\mathrm{a}}$ \\
\hline P-level & NS & 0.01 & 0.01 & 0.01 & 0.01 & 0.01 & NS & 0.01 & 0.01 & 0.01 & 0.01 & 0.01 \\
\hline $\mathrm{CV} \%$ & 1.41 & 2.23 & 3.64 & 5.67 & 21.58 & 21.58 & 3.76 & 5.09 & 2.66 & 3.80 & 3.80 & 3.80 \\
\hline $\mathrm{SE}( \pm)$ & 0.08 & 0.23 & 0.40 & 0.68 & 0.67 & 0.67 & 0.05 & 0.18 & 0.25 & 0.31 & 0.29 & 0.29 \\
\hline
\end{tabular}

In a column, means of similar letter (s) do not differ significantly. DAT = Days After Treatment, P-level = Probability Level, CV = Co-efficient of Variation,

$\mathrm{SE}=$ Standard Error.

\section{CONCLUSIONS}

Minimum and/or selective use of insecticides in effective doses and frequencies would be helpful in the long run for the conservation and survival of predators Lycosa pseudoannulata and Ophionea indica in rice ecosystem for brown planthopper. Significant reduction of predators was observed through nonselective or direct chemical insecticide in respect of selective or IGR based insecticides causing adverse effects on natural enemies, environments and others. From the point of view, it could be concluded that, Buprofezin and Lufenuron can be applied as a safer and protector for the wolf spider and carabid beetle populations than Thiacloprid.

\section{ACKNOWLEDGEMENTS}

The study was supported by the Department of Entomology, Bangladesh Agricultural University, Mymensingh through separated field facilities. We especially thanks to Bangladesh Institute of Nuclear Agriculture (BINA), Mymensingh to collaborate us in supplying seedling materials.

\section{REFERENCES}

Ali Khan, M. A., and Yusuf, M. (1986). Temperature and food requirement of chilomenes sexmaculata. Environment Entomology, 15, 800-802.

Aulakh, S.S., and Butter, N.S. (2009). Conservation of natural enemies in cotton ecosystem with pre-dosing of Lufenuron prior to the use of traditional insecticides. Journal of Biological Control, 23(3), 233-241.

Biswas, T.K., Rahman, M.A., Khan, M.M.H., Alam, M.M. and Jahan, M. (2006). Toxic Effects of Two Insecticides on Brown Plant Hopper, Nilaparvata lugens and its Predators Micraspis discolor and Lycosa pseudoannulata. International Journal of Zoological Research, 2, 192-203.

Bonn, A., and Kleinwachter, M. (1999). Relation between brown planthopper, Nilaparvata lugens and carabid beetle, Ophionea indica. Zeitschrift Fur Okologic und Naturchutz, 8, 109-123.
Choi, B.R., Heong, K.L., Lee, J.O., Yoo, J.K., and Park, C.G. (1996). Effects of sub-lethal doses of insecticides on the brown planthopper, Nilaparvata lugens (Stål) (Homoptera: Delphacidae) and mirid predator, Cyrtorhinus lividipennis (Reuter) (Hemiptera: Miridae). Korean Journal of Applied Entomology, 35(1), 52-57.

Deng, L., Xu, M., Cao, H., and Dai, J. (2008). Ecotoxicological Effects of Buprofezin on Fecundity, Growth, Development, and Predation of the Wolf Spider Piratapiratoides (Schenkel). Archives of Environmental Contamination and Toxicology, 55, 652-658.

Gogi, M.D., Sarfraz, R.M., Dosdall, L.M., Arif, M.J., Keddie, A.B., and Ashfaq, M. (2006). Effectiveness of two insect growth regulators against Bemisia tabaci (Gennadius) (Homoptera: Aleyrodidae) and Helicoverpa armigera (Hübner) (Lepidoptera: Noctuidae) and their impact on population densities of arthropod predators in cotton in Pakistan. Pest Management Science, 62(10), 982-990.

Gomez, K.A., and Gomez, A.A. (1984). Statistical procedures for agricultural research (2 ed.) (680). New York, John wiley and sons.

GuiFen, Z., and ChuanTao, L. (1996). Trials on control of plant hoppers with Imidacloprid in fields. Plant Protection, 22(2), 48-49.

Husain, M. (1993). Anistakar Kit-Patanga Damon (control) of harmful insects (pp. 220). Dhaka, Bangladesh, Bangla Academy.

Kiritani, K. (1979). Pest management in rice. Annual Review of Entomology, 24, 279-312

Luckmann, W.H., and Metcalf, R.L. (1975). The Pest Management Concept. In: Metcalf RL and Luckman WH (Editors). Introduction of insect pest management (pp. 3-35). New York, USA, John Wiley and Sons.

Mendel, Z., Blumberg, D., and Ishaaya, I. (1994). Effects of some insect growth regulators on natural enemies of scale insects (Homoptera: Coccoidea). Entomophaga, 39(2), 199-209.

Samal, P., and Misra, B.C. (1984). Ophionea indica, a predatory carabid beetle of rice brown planthopper, Nilaparvata lugens (Stal.). Oryza, 19, 212.

Tanaka, K., Endo, S., and Kazano, H. (2000). Toxicity of insecticides to predators of rice planthoppers: spiders, the mirid bug and the dryinid wasp. Applied Entomology and Zoology, 35(1), 177-187. 
Thang, M.H., Mochida, O., Morallo-Rejesus, B., and Robles, R.P. (1987). Selectivity of eight insecticides to the brown planthopper Nilaparvata lugens (Stål) (Homoptera :Delphacidae), and its predator, the wolf spider, Lycosa pseudoannulata (Boes. et str.) (Araneae: Lycosidae). Philippine Entomologist, 7(1), 51-66.

Ullah M.S., and Jahan, M. (2004). Schedule and need based chemical control of brown planthopper and their impact on the predator Ophionea indica (Thunberg). Asian Journal of Plant Sciences, 3(6), 687-689.

Zeng, M.S., Liu, F.J., Wang, D.F., Yu, S.H., and Wu, G.Y. (2010). Control effect of Thiacloprid 48 SC against Empoasca vitis (Gothe), Toxoptera aurantii (Boyer) and its safety evaluation. Agrochemicals, 11, 27. 